\title{
Inhibition of Growth and RNA Biosynthesis of Bacillus cereus by Quinacrine
}

\author{
By M. L. SELIGMAN* AND H. G. MANDEL \\ Department of Pharmacology, The George Washington University School of \\ Medicine, Washington, D.C. 20005, U.S.A.
}

(Accepted for publication 7 July 1971)

\section{SUMMARY}

The addition of 0.4 mM-quinacrine to exponential cultures of Bacillus cereus led to the complete inhibition of growth, measured turbidimetrically. Certain metal ions such as $\mathrm{Ca}^{2+}$ and $\mathrm{Mg}^{2+}$ were partially effective in preventing growth inhibition, as was the polyamine spermine.

Quinacrine inhibited most biosynthetic processes measured to the same extent as the reduction in the rate of growth. Thus the incorporation of amino acids into protein, that of diaminopimelic acid into bacterial wall, the accumulation of $\mathrm{K}^{+}$ and the uptake of nicotinic acid were diminished only in accordance with the decreased rate of turbidimetric increase. DNA biosynthesis was decreased to a lesser extent than was turbidity and continued even after growth had ceased altogether, thus indicating less inhibition of this process than that of protein formation. RNA synthesis, on the other hand, was selectively inhibited in these cells. The depressant effect was most pronounced when ribosomal or rRNA formation was examined. RNA isolated from drug-treated cells still exhibited messenger function. An additional effect of quinacrine on the uptake of certain nucleic acid bases is also postulated. The relative content of ATP in the cells was considerably increased by drug treatment.

It appears that quinacrine did not exert its major action on DNA biosynthesis but selectively blocked RNA formation while that of DNA was permitted to continue.

\section{INTRODUCTION}

It is generally assumed that the antimalarial drug, quinacrine, owes its growth-inhibitory properties to a complexing with DNA (Irvin \& Irvin, I954; Kurnick \& Radcliffe, I962; Lerman, I963; O'Brien, Olenick \& Hahn, I966) which leads to the failure of strand separation and the cessation of DNA synthesis (Ciak \& Hahn, 1967). It therefore became of interest to examine the actions of the drug in a microbial system, Bacillus cereus, in which DNA synthesis continued while growth was completely inhibited (Mandel \& Seligman, 1966, 1967).

\section{METHODS}

Bacterial growth and sampling. Bacillus cereus $569 \mathrm{H}$ was grown at $37^{\circ}$ in a New Brunswick Scientific Co. gyrotary shaker, Model G-25. The growth medium (Grünberger \& Mandel, I965) contained, per litre: $\mathrm{KH}_{2} \mathrm{PO}_{4}, \mathrm{I} \cdot 5 \mathrm{~g}$.; $\mathrm{MgSO}_{4} \cdot 7 \mathrm{H}_{2} \mathrm{O}, 0.5 \mathrm{I}$ g.; $\mathrm{Fe}\left(\mathrm{NH}_{4}\right)_{2}\left(\mathrm{SO}_{4}\right)_{2} \cdot 6 \mathrm{H}_{2} \mathrm{O}$, $4.8 \mathrm{mg}$.; $\mathrm{K}_{2} \mathrm{SO}_{4}, \mathrm{I} \cdot 5 \mathrm{~g}$.; $\mathrm{MnSO}_{4}$, $0.5 \mathrm{mg}$.; tris, $2.0 \mathrm{~g}$.; and Casamino acids, $10.0 \mathrm{~g}$. The solution was then adjusted to $\mathrm{pH} 7 \cdot 2$ with hydrochloric acid. The typical doubling time was $50 \mathrm{~min}$.

\footnotetext{
* Present address: Department of Pathology, New York University, New York, N.Y.
} 
The membrane filtration and fractionation technique described by Roodyn \& Mandel ( $1960 a$ ) was used to study the incorporation of various radioactive precursors into macromolecules and acid-soluble pools. Additions were made at bacterial turbidities $(540 \mathrm{~nm}$.) varying between $\mathrm{O}^{\circ} \mathrm{I}$ and $0^{\circ} \cdot 2$, corresponding to concentrations of 50 to $100 \times \mathrm{IO}^{6}$ cells per ml. of suspension. A suspension of Bacillus cereus, to which the desired labelled compound had been added (nucleic acid precursors, $0.01 \mu \mathrm{Ci} / \mathrm{ml}$. medium; amino acids, $0.2 \mu \mathrm{Ci} / \mathrm{ml}$. medium, ${ }^{42} \mathrm{~K}^{+}$, I $\mu \mathrm{Ci} / \mathrm{ml}$. medium) was incubated at $37^{\circ}$ in the shaker, and at timed intervals $2 \mathrm{ml}$. of the growing bacterial suspension was added to $2 \mathrm{ml}$. of an appropriate solution (I0\% trichloroacetic acid (TCA), I M-KOH, or saline). This mixture was filtered on to Schleicher and Schuell B-6 membrane filters and washed twice with $5 \mathrm{ml}$. portions of either I \% trichloroacetic acid (for the acid or alkali treatment) or saline. The filters were air dried, glued on to aluminium planchets and radioactivity counted to $2 \%$ error in a Nuclear Chicago windowless gas-flow counter, using natural gas. Treatment of cells with trichloroacetic acid precipitated protein, nucleic acids and cell wall. Exposure to alkali permitted complete retention of the DNA on the filter. The difference between the saline-washed and acid-treated cells represented the acid-soluble pool fraction (Roodyn \& Mandel, 1960 a).

For the assays for RNA (Militzer, 1946) and DNA (Burton, 1955) it was necessary to remove quinacrine from perchloric acid extracts of cells. The extracts were therefore made alkaline with Io $\mathrm{N}-\mathrm{NaOH}$, extracted twice with $\mathrm{CCl}_{4}$ to remove the drug, and then were reacidified with $\mathrm{HCl}$.

Incorporation of isotopic precursors and content of cellular components have been plotted against turbidity of the bacterial culture, measured at $540 \mathrm{~nm}$., to observe effects of the drug that differed from those on growth.

ATP assay. (a) Luciferase solution: Sigma FLE-50 desiccated firefly tails (50 mg.) was added to make a $5 \mathrm{ml}$. aqueous solution of final concentration $0.05 \mathrm{M}-\mathrm{KH}_{2} \mathrm{AsO}_{4}$ and $0.02 \mathrm{M}-$ $\mathrm{MgSO}_{4}, \mathrm{pH} \mathrm{7} \cdot 4$. The mixture was shaken vigorously for $2 \mathrm{~min}$. and centrifuged at $14,500 \mathrm{~g}$ for $35 \mathrm{~min}$. in a Sorvall refrigerated centrifuge. The supernatant was decanted and stored at $-10^{\circ}$ overnight before use. Insignificant loss of enzyme activity occurred on freezing and thawing of the supernatant, and this procedure provided reproducible readings. $(b)$ Arsenate buffer: Stock Sigma FF-As arsenate buffer (0.I M) was diluted to $0.006 \mathrm{M}$ with distilled water. This buffer prevents the rapid decay of luminescence (Strehler \& Totter, I954). (c) Adaptation of spectrometer for assay of ATP. A Beckman DPM-Ioo liquid scintillation counter with coincidence circuit disconnected was employed, and the third repetitive $6 \mathrm{~s}$. count after the addition of the enzyme was used for calculations. Luminescence intensity was measured on a variable discriminator module set from 3 to 100 units, and the background was around 3500 c.p.m. per 6 s. (Addanki, Sotos \& Rearick, 1966). The method was linear from I to Io nM ATP. (d) Assay of bacterial ATP content: Samples (I ml.) of suspension taken from treated or control suspensions of bacteria, or filtrates of such suspensions after membrane filtration, were added to $4 \mathrm{ml}$. of boiling water within $\mathrm{r} 5 \mathrm{~s}$. after removal from the culture. The samples were then boiled for Io min., placed in ice to cool, and a portion assayed for ATP. In a partially darkened room with only indirect incandescent light a mixture of $3.8 \mathrm{ml}$. of arsenate buffer with $0.2 \mathrm{ml}$. of enzyme solution at $0^{\circ}$ was mixed and luminescence immediately assayed in the counter; the third repetitive $6 \mathrm{~s}$. count was recorded as the background value. Then $0.2 \mathrm{ml}$. of the ATP standard or bacterial extract was added, the mixture again mixed and assayed. The ATP concentration was recorded as counts/sec. and then converted to nmoles from a standard curve. The cells contained about nine-tenths of the ATP content of the bacterial suspension. Quinacrine added directly to the ATP assay system had no effect on luminescence. 
Isolation and assay of subcellular components. Ribosomes and ribosomal subunits were isolated from Bacillus cereus by the procedures of Connamacher \& Mandel (I965). RNA was prepared by the cetyl trimethylammonium bromide method (Ralph \& Bellamy, 1964) as modified by Grünberger \& Mandel (1965).

Cell-free polyphenylalanine synthesis was measured according to the method of Nirenberg (1963). Different quantities of RNA from control and quinacrine-treated Bacillus cereus $(0.4 \mathrm{mM}, 60 \mathrm{~min}$. of inhibition) were added to the in vitro incubation system containing an incubated S-30 fraction from Escherichia coli $\mathrm{I} 1303$ cells, as described by Grünberger \& Mandel (1965). After incubation for o, 15 and $30 \mathrm{~min}$. at $37^{\circ}$ the reaction was stopped by the addition of $10 \%$ TCA. The suspension was then heated for $30 \mathrm{~min}$. in a boiling water bath to hydrolyse any aminoacyl-RNA, cooled in ice for I $5 \mathrm{~min}$. to insure complete precipitation, and then filtered on to membrane filters. The precipitates were washed four times with $5 \mathrm{ml}$. of $5 \%$ TCA containing $0 . \mathrm{I} \%$ casamino acids, and after drying were placed in scintillation vials with Io ml. Bray's (1960) solution. Samples were counted in a Beckman DPM-I oo liquid scintillation counter.

Sources of radioisotopes and quinacrine. $\left[{ }^{1-14} \mathrm{C}\right]$ Glycine, $\left[\mathrm{U}-{ }^{14} \mathrm{C}\right] \mathrm{L}-\mathrm{phenylalanine,}\left[{ }^{-14} \mathrm{C}\right]-$ adenine, $\left[2-{ }^{14} \mathrm{C}\right]$ uracil, $\left[\mathrm{I}-{ }^{14} \mathrm{C}\right] \mathrm{D}, \mathrm{L}-l e u c i n e,\left[2-{ }^{14} \mathrm{C}\right]$ thymidine, $\left[{ }^{14} \mathrm{C}\right]$ formate, $\left[2-{ }^{14} \mathrm{C}\right]$ diaminopimelic acid, $\left[7^{-14} \mathrm{C}\right]$ nicotinic acid, $\left[7^{-14} \mathrm{C}\right]$ nicotinamide, $\left[8-{ }^{14} \mathrm{C}\right]$ hypoxanthine, $\left[8^{-14} \mathrm{C}\right]$ guanine, and $\left.{ }^{32} \mathrm{P}\right]$ phosphate (monosodium salt) were purchased from New England Nuclear Corporation, Waltham, Massachusetts. ${ }^{42} \mathrm{~K}^{+}$was purchased from Isoserve Cambridge Nuclear Corporation, Cambridge, Massachusetts. $\left[8-{ }^{14} \mathrm{C}\right]$ Adenosine came from Calbiochem, Inc., Los Angeles, California. Quinacrine hydrochloride was supplied by the Walter Reed Army Institute of Research, Washington, D.C.

\section{RESULTS}

Effect of quinacrine on growth and cell morphology of Bacillus cereus. Quinacrine at o. I $\mathrm{mM}$ inhibited the growth of exponentially growing Bacillus cereus (Fig. I). The rate of growth, measured turbidimetrically, remained exponential but was slower than that of control bacteria. With increasing drug concentrations the growth rate decreased further. After $\mathrm{I} \cdot 5 \mathrm{~h}$. at 0.4 mM-quinacrine, complete cessation of growth was followed by a decline in turbidity, suggesting cell lysis.

Resuspension of quinacrine-treated cells in fresh medium in the absence of the drug resulted in normal growth, providing that contact with the drug had not exceeded $\mathrm{I} h$. Cloning of cells following $\mathrm{I} \mathrm{h}$. of inhibition at $0.4 \mathrm{~mm}$-quinacrine indicated no loss of viability. After $90 \mathrm{~min}$. of growth in the presence of $0.4 \mathrm{~mm}$-quinacrine, the inhibited cells failed to recover upon resuspension.

Bacteria treated with quinacrine $(0.4 \mathrm{~mm})$ for $90 \mathrm{~min}$. had lost the ability to Gram stain. The length of the inhibited bacteria was slightly greater, with considerable variation among them. In contrast to the controls, inhibited bacteria formed chains of three to seven. Although counts were impeded by chain formation and some clumping, no significant difference in number could be established visually between cultures grown with $0.4 \mathrm{~mm}$-quinacrine for $90 \mathrm{~min}$. and controls assayed at identical bacterial turbidities.

Prevention of growth inhibition. Various metal ion supplements were tested in the Bacillus cereus system for their ability to protect against the inhibitory actions of quinacrine. $\mathrm{Ca}^{2+}$ $(5 \mathrm{~mm})$ or $40 \mathrm{~mm}-\mathrm{Mg}^{2+}$ completely prevented the effect of $0.1 \mathrm{~mm}$-quinacrine, and $0.3 \mathrm{~mm}-$ $\mathrm{Mn}^{2+}$ or $400 \mathrm{~mm}-\mathrm{K}^{+}$partially overcame the growth inhibition. $\mathrm{Na}^{+}$had no effect even at 
$400 \mathrm{mM} . \mathrm{Mg}^{2+}$ was only partially effective in a concentration-dependent manner in preventing growth inhibition in the presence of 0.4 mM-quinacrine (Fig. $2 a$ ).

Spermine $(\mathrm{I} \cdot 2 \mathrm{mM})$ prevented the inhibition of $0.1 \mathrm{mM}$-quinacrine, but was only partially effective at higher concentrations of quinacrine (Fig. $2 b$ ). The combined addition of $\mathrm{I} \cdot 2 \mathrm{~mm}-$ spermine and $40 \mathrm{~mm}-\mathrm{Mg}^{2+}$ was more effective in antagonizing the growth-inhibitory effects of quinacrine than either agent alone but still did not permit normal growth. At the concentrations used, neither spermine nor $\mathrm{Mg}^{2+}$ alone affected normal growth.

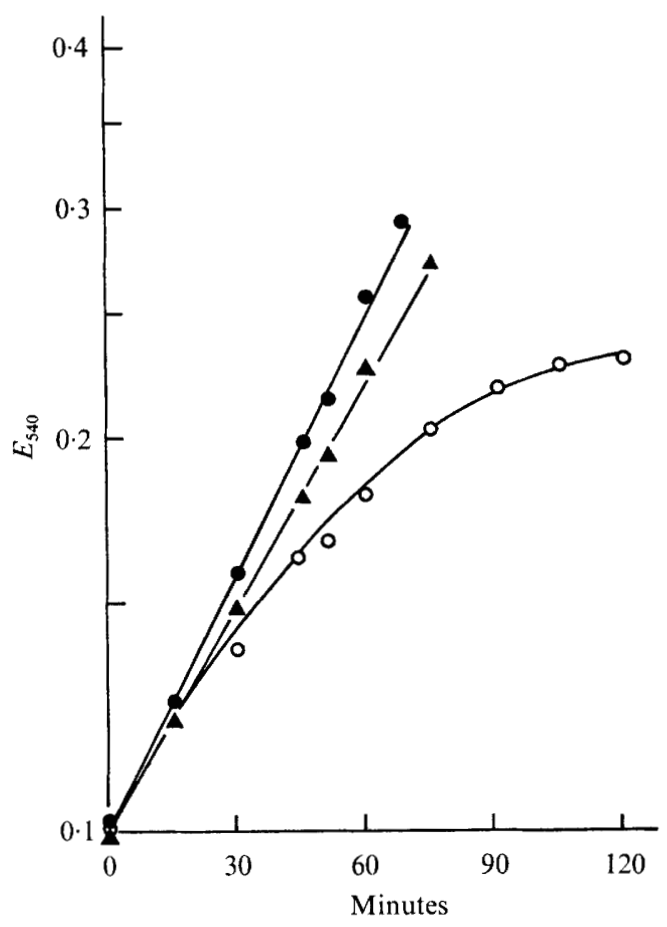

Fig. I. Effect of quinacrine on growth of Bacillus cereus. Growth was measured turbidimetrically at $540 \mathrm{~nm}$. in a Beckman DU spectrophotometer. Quinacrine was added at zero time at concentrations: , $0 ; \Delta, 0.1 \mathrm{~mm}(50 \mu \mathrm{g} . / \mathrm{ml}$.); and $\bigcirc, 0.4 \mathrm{~mm}$.

Effect on protein and cell wall formation. The effect of quinacrine on the incorporation of labelled precursors for specific cellular constituents was measured by assay of radioactivity in bacteria collected from cultures growing in the presence and absence of the drug. Experiments using $\left[{ }^{[4} \mathrm{C}\right]$ leucine or $\left[{ }^{14} \mathrm{C}\right]$ phenylalanine, which specifically label bacterial protein (Roodyn \& Mandel, $(960 \mathrm{~b}$ ), revealed that quinacrine, up to $0.4 \mathrm{mM}$, provided no selective inhibition of protein synthesis (Fig. $3 a$ ) when cultures were compared after growth to the same turbidity.

The incorporation of $\left[{ }^{14} \mathrm{C}\right]$ diaminopimelic acid into Bacillus cereus, a measure of wall biosynthesis, also was unaffected by quinacrine. Furthermore, $\left.{ }^{\left[\mathrm{I}-{ }^{14}\right.} \mathrm{C}\right]$ glycine incorporation into the hot trichloroacetic acid-insoluble residue which represents both wall and protein (Roodyn \& Mandel, I960 $b$ ), was unchanged. Thus, no selective inhibition of wall synthesis by quinacrine could be detected (Fig. $3 b$ ).

Effect on DNA formation. DNA content, measured by the diphenylamine method (Burton, 1955), was slightly increased in cultures inhibited by 0.1 mM-quinacrine when comparison was made at similar turbidities (Fig. 4a). At 0.4 mM-quinacrine the increase was more 


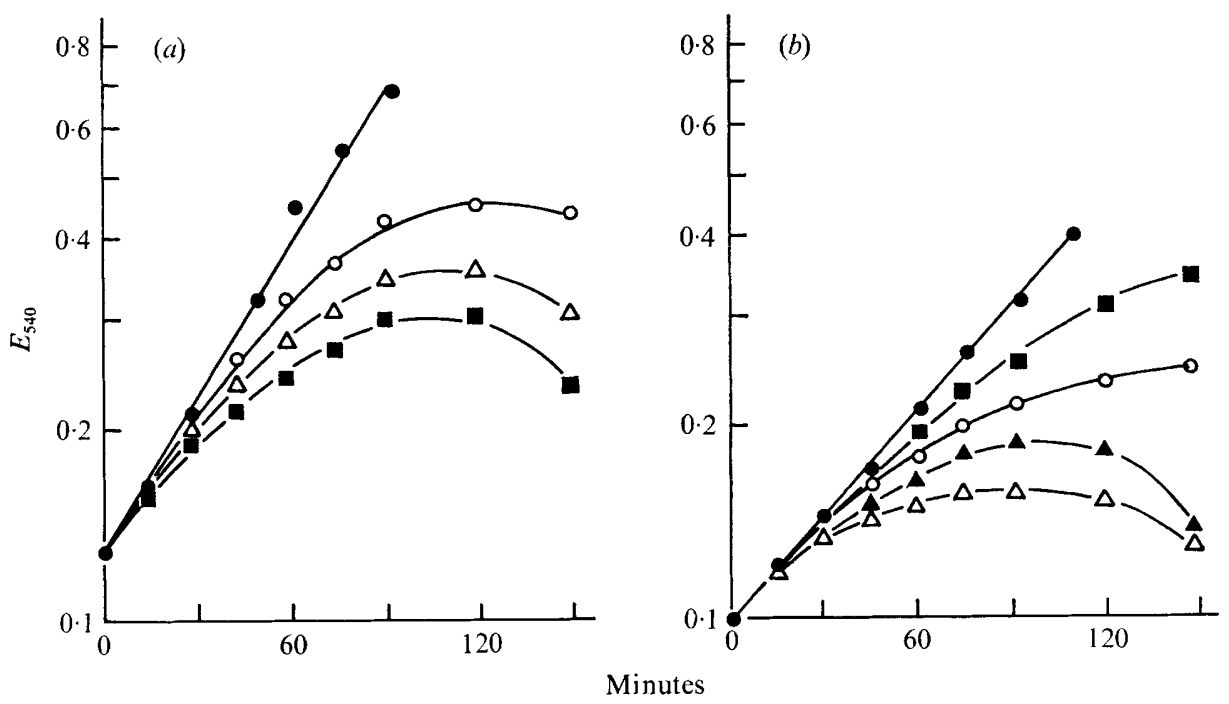

Fig. 2. Prevention of quinacrine-produced growth inhibition by $\mathrm{Mg}^{2+}$ and spermine. (a) Supplementation of medium (normally $2 \mathrm{mM}-\mathrm{Mg}^{2+}$ ) with $\mathrm{Mg}^{2+}: \mathcal{O}$, control with either 2 or $40 \mathrm{mM}^{-\mathrm{Mg}^{2+}}$; 口, $0.4 \mathrm{~mm}$-quinacrine, $2 \mathrm{~mm}-\mathrm{Mg}^{2+} ; \triangle, 0.4 \mathrm{~mm}$-quinacrine, $20 \mathrm{mM}^{-\mathrm{Mg}^{2+}} ; 0,0.4 \mathrm{~mm}$-quinacrine, $40 \mathrm{mM}-\mathrm{Mg}^{2+}$. (b) Supplementation with $\mathrm{Mg}^{2+}$ and spermine: $\bigcirc$, control medium with either $2 \mathrm{mM}-$ $\mathrm{Mg}^{2+}, 40 \mathrm{mM}-\mathrm{Mg}^{2+}$ or with $\mathrm{I} \cdot 2 \mathrm{~mm}$-spermine; $\triangle, 0.4 \mathrm{~mm}$-quinacrine, $2 \mathrm{mM}-\mathrm{Mg}^{2+}$ only; $\Delta, 0.4 \mathrm{mM}-$ quinacrine, $2 \mathrm{mM}-\mathrm{Mg}^{2+}, \mathrm{I} \cdot 2 \mathrm{~mm}$-spermine; $\mathrm{O}, 0.4 \mathrm{~mm}$-quinacrine, $40 \mathrm{~mm}-\mathrm{Mg}^{2+}$, no spermine; and D, 0.4 mM-quinacrine, $40 \mathrm{~mm}-\mathrm{Mg}^{2+}, \mathrm{I} \cdot 2 \mathrm{~mm}$-spermine.
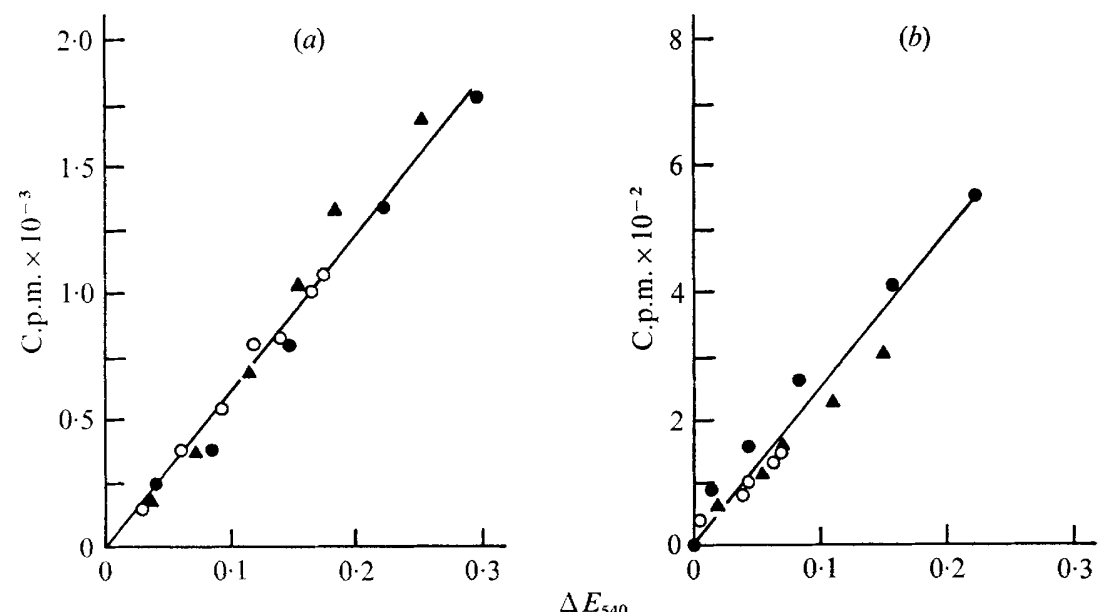

Fig. 3. Lack of selective effect of quinacrine on bacterial protein and wall biosynthesis. (a) Incorporation of radioactivity from $\left[\mathrm{I}^{14} \mathrm{C}\right]$ leucine in the growth medium into bacteria followed by treatment with trichloroacetic acid. All of the radioactivity was recovered in the protein of the bacteria. Radioactivity in cells per $2 \mathrm{ml}$. of culture, measured after membrane filtration and plotted against increase in bacterial culture density. (b) Similar experiments with $\left[2-{ }^{14} \mathrm{C}\right]$ diaminopimelic acid, in which the wall was labelled exclusively. Quinacrine concentrations:, $0 ; \boldsymbol{\Lambda}, 0.2 \mathrm{~mm} 0,0.4 \mathrm{~mm}$. 
pronounced. Results from experiments on the incorporation of $\left[2-{ }^{14} \mathrm{C}\right]$ thymidine into the bacteria, which labels DNA exclusively, were essentially similar to those using the colorimetric reaction for DNA (Fig. $4 b$ ), and again demonstrated greater incorporation during quinacrine treatment for the same increase in turbidity. The incorporation of [ $\left.{ }^{32} \mathrm{P}\right]$ phosphate into the $\mathrm{KOH}$-insoluble fraction, which also serves as a crude assay for DNA synthesis, was similarly affected.

On the other hand, the incorporation of the purines, $\left[{ }^{14} \mathrm{C}\right]$ adenine, $\left[{ }^{14} \mathrm{C}\right]$ guanine, and $\left[{ }^{14} \mathrm{C}\right]$ hypoxanthine, and of the pyrimidine $\left[{ }^{14} \mathrm{C}\right]$ uracil into the $\mathrm{KOH}$-insoluble bacterial fraction, procedures which measure incorporation into DNA exclusively (Roodyn \& Mandel, I960a), remained unaffected by quinacrine (Fig. $4 c$ ). These results were surprising in view of the increases observed in thymidine incorporation or the colorimetric assay (Figs. $4 a$
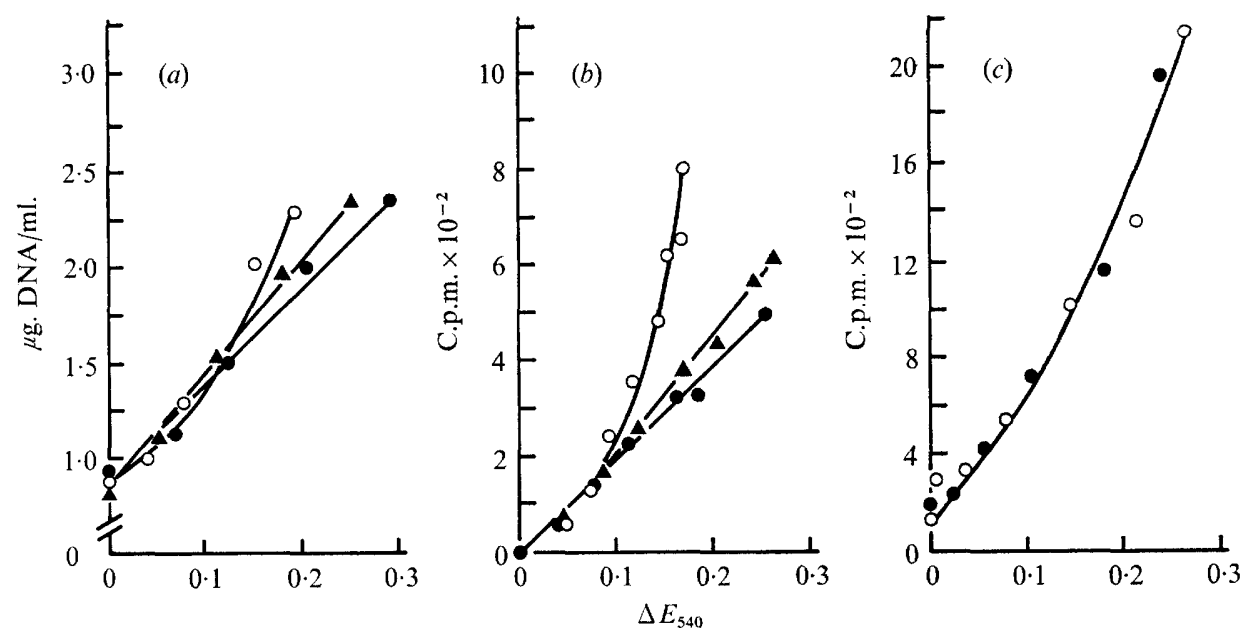

Fig. 4. Effect of quinacrine on DNA biosynthesis. (a) DNA content by diphenylamine reaction; (b) incorporation of radioactivity from $\left[2-{ }^{14} \mathrm{C}\right]$ thymidine into DNA; $(c)$ incorporation of $\left[8-{ }^{14} \mathrm{C}\right]-$ guanine into bacteria followed by addition of $\mathrm{KOH}$, to measure incorporation into DNA only. Presentation as in Fig. 3. Quinacrine concentrations:, $0 ; \boldsymbol{\Delta}, 0.1 \mathrm{mM} ; 0,0.4 \mathrm{mM}$.

and $b$ ), and may be due to an additional effect of quinacrine in inhibiting the uptake of these nucleic acid bases, as described below. In any case, DNA biosynthesis clearly was not inhibited by quinacrine, and actually appeared to be greater in the presence of the drug when analyses were made for cultures grown to similar turbidities.

Effect on RNA formation. The incorporation of purines and pyrimidines into nucleic acids, about $95 \%$ of which is RNA (Roodyn \& Mandel, I960a) was inhibited by quinacrine. Studies using $\left[{ }^{14} \mathrm{C}\right]$ adenine, $\left[{ }^{14} \mathrm{C}\right]$ adenosine, $\left[{ }^{14} \mathrm{C}\right]$ guanine, $\left[{ }^{14} \mathrm{C}\right]$ hypoxanthine or $\left[{ }^{14} \mathrm{C}\right]$ uracil all readily revealed a potent inhibitory effect of quinacrine on the incorporation of these nucleic acid bases into RNA (Fig. $5 a$ ). The effect of the drug on $\left[{ }^{14} \mathrm{C}\right]$ formate incorporation into RNA also was similar, and the incorporation of $\left[{ }^{32} \mathrm{P}\right]$ phosphate was also reduced. When RNA content was measured by the orcinol method (Militzer, 1946) (Fig. $5 b$ ), increases in the content of ribose of the quinacrine-treated cultures gradually ceased altogether even though the bacterial turbidity was still rising. These effects on RNA synthesis clearly differed from the results cited previously with protein, cell wall and DNA formation, and thus represented a selective effect of quinacrine on this component.

In these experiments it was usually observed that the effect of quinacrine on the incorporation of a preformed purine or pyrimidine was more pronounced for similar increases in 
bacterial turbidity than that on RNA measured colorimetrically, even after calculating RNA content for the newly formed cells only ( $\triangle$ RNA) (Table I). Whereas $\triangle$ RNA of quinacrine-treated cultures measured colorimetrically was near $70 \%$ of control, the incorporation of radioactive adenine, guanine, hypoxanthine and uracil was about $40 \%$ of control. This distinction is also evident in comparing Fig. $5 a$ with $5 b$ at $\triangle E$ of $0 \cdot 1$, before RNA synthesis ceased altogether. Although some variability might be expected in comparing the different experiments because of differences in pool sizes and the progressive inhibition of RNA synthesis after the addition of the drug, this discrepancy was also observed when the
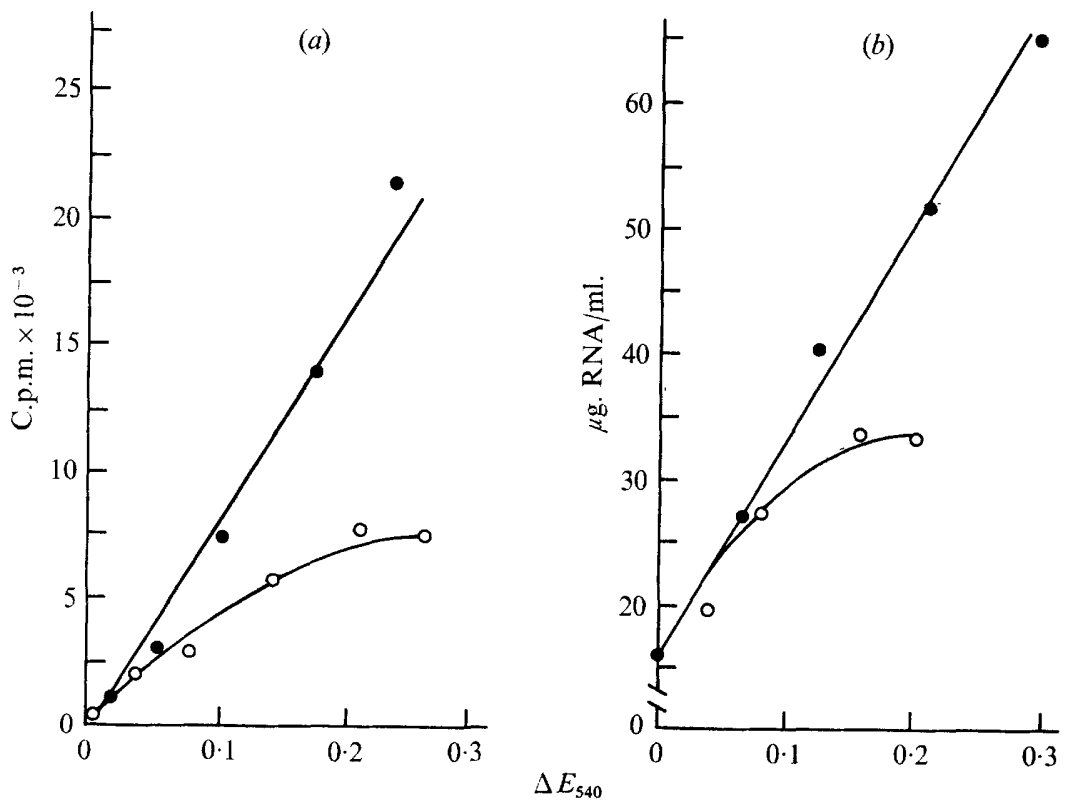

Fig. 5. Effect of quinacrine on RNA biosynthesis. (a) Incorporation of radioactivity from $\left[8-{ }^{14} \mathrm{C}\right]-$ adenine into nucleic acids ( $95 \%$ RNA); $(b)$ RNA content by the orcinol reaction. Presentation as in Fig. 3. Quinacrine concentrations, O, $0 ; 0,0.4 \mathrm{~mm}$.

Table I. Effect of quinacrine $(Q)$ on $R N A$ synthesis, measured by various procedures

Bacillus cereus cultures were grown for similar increases in bacterial turbidity in presence of varying concentrations of drug. Content of ribose (Militzer, 1946) has been calculated for newly formed cells only by subtraction of zero-time values.

RNA synthesis, $\%$ of control

\begin{tabular}{|c|c|c|c|c|c|c|}
\hline \multirow[b]{2}{*}{ Expt. no. } & \multicolumn{3}{|c|}{ By ribose content or ${ }^{32} \mathrm{P}$ incorporation } & \multicolumn{3}{|c|}{ By base incorporation } \\
\hline & Assay & $0.1 \mathrm{mM} \mathrm{Q}$ & $0.4 \mathrm{~mm} \mathrm{Q}$ & Precursor & O. I mM Q & $0.4 \mathrm{~mm} \mathrm{Q}$ \\
\hline I & Ribose & 89 & 62 & -- & - & - \\
\hline 2 & Ribose & 92 & 68 & - & - & - \\
\hline & Ribose & 96 & 90 & - & - & - \\
\hline 3 & $\left\{{ }^{32} \mathbf{P}\right.$ & $9 \mathrm{I}$ & $8 \mathrm{I}$ & - & - & - \\
\hline 4 & Ribose & 88 & 68 & {$\left[{ }^{[14} \mathrm{C}\right]$ Uracil } & 84 & 30 \\
\hline 5 & - & - & - & {$\left[{ }^{14} \mathrm{C}\right]$ Uracil } & - & 40 \\
\hline 6 & - & - & - & {$\left[{ }^{14} \mathrm{C}\right]$ Adenine } & 66 & $3 \mathrm{I}$ \\
\hline 7 & - & - & - & {$\left[{ }^{14} \mathrm{C}\right]$ Adenine } & 73 & 36 \\
\hline 8 & - & - & - & {$\left[{ }^{14} \mathrm{C}\right]$ Guanine } & - & 54 \\
\hline 9 & - & - & - & {$\left[{ }^{14} \mathrm{C}\right]$ Hypoxanthine } & - & 38 \\
\hline
\end{tabular}


two measurements were made on the same culture. It appears, therefore, that quinacrine, in addition to producing a direct inhibition of RNA synthesis, also exerted a blocking action on the utilization of certain purines and pyrimidines. This latter drug effect may be due to a diminished uptake of these bases.

The addition of $1 \cdot 2 \mathrm{mM}$-spermine, which had been shown to protect against the growth inhibition associated with 0.4 mM-quinacrine (Fig. $2 b$ ), also protected against the selective depressant effect of quinacrine on $\left[{ }^{14} \mathrm{C}\right]$ adenine incorporation into nucleic acids (Fig. 6).

Stability of RNA formed in the presence of quinacrine. The stability of RNA formed during growth inhibition by 0.4 mM-quinacrine was tested during subsequent growth in the presence or absence of $0.4 \mathrm{~mm}$-quinacrine. Bacteria grown in the presence of $\left[{ }^{14} \mathrm{C}\right]$ adenine and

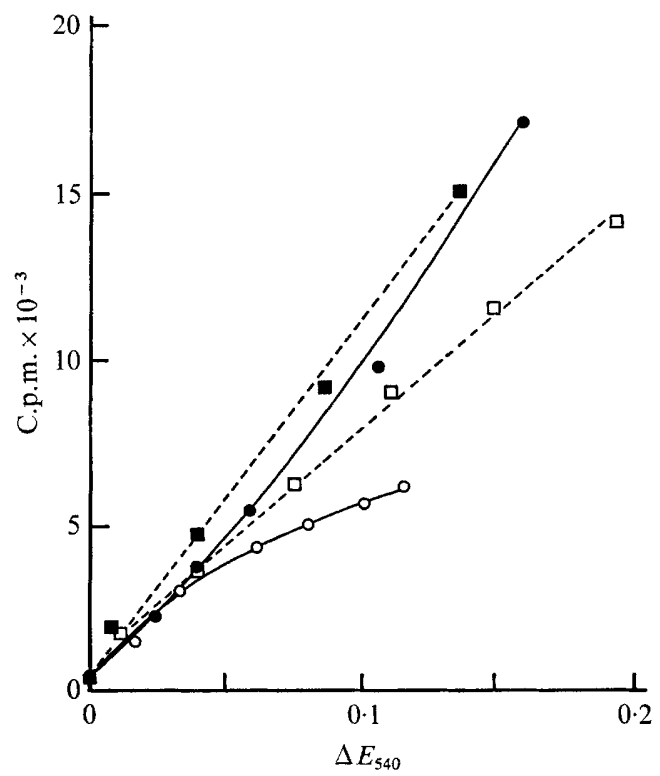

Fig. 6. Effect of spermine on $\left[{ }^{14} \mathrm{C}\right]$ adenine incorporation into the nucleic acids of cells growing in the presence and absence of quinacrine. All additions made at zero time. Concentrations: 0,0 ;

$\square, \mathrm{I} \cdot 2 \mathrm{~mm}$-spermine; $O, 0.4 \mathrm{~mm}$-quinacrine; $\square, \mathrm{I} \cdot 2 \mathrm{mM}$-spermine, plus $0.4 \mathrm{~mm}$-quinacrine.

quinacrine were resuspended in fresh non-radioactive medium, and samples were removed periodically and assayed for radioactivity in the nucleic acids. The constancy of radioactivity in the bacteria suggested that RNA synthesized during growth inhibition was stable during subsequent growth.

Localization of RNA effect among subcellular components. To determine if the effect of quinacrine on RNA synthesis could be associated preferentially with a subcellular component of Bacillus cereus, ribosomes, ribosomal subunits and rRNA were prepared from bacteria grown with labelled nucleic acid precursors in the presence or absence of quinacrine. Fig. 7 reveals that the curtailment of incorporation of radioactivity was associated mainly with 70 s ribosomes and the two component rRNA fractions. The drug's effect on labelling of sRNA was less pronounced.

The ability of RNA synthesized by Bacillus cereus in the presence of quinacrine to stimulate the incorporation of phenylalanine into polypeptide was measured by the use of an incubated Escherichia coli s-30 system. (Nirenberg, 1963) requiring exogenous messenger 
such as polyU. Fractionation of this total RNA from $B$. cereus has revealed that the major proportion of the template activity was present in the region between $4 \mathrm{~S}$ and $16 \mathrm{~s}$, as would be expected for mRNA. A small proportion was associated with the $\mathrm{I} 6 \mathrm{~s}$ component, whereas the 23S rRNA region possessed almost no template activity (Grünberger \& Mandel, 1965). RNA was extracted from $B$. cereus cultures grown to similar turbidities in the presence or absence of 0.4 mM-quinacrine, and the ability of these RNA fractions to stimulate phenylalanine incorporation was compared. The two RNA fractions behaved identically (Fig. 8), indicating that quinacrine treatment had not produced a depressant effect on messenger activity of RNA greater than that on the combined RNA fractions.

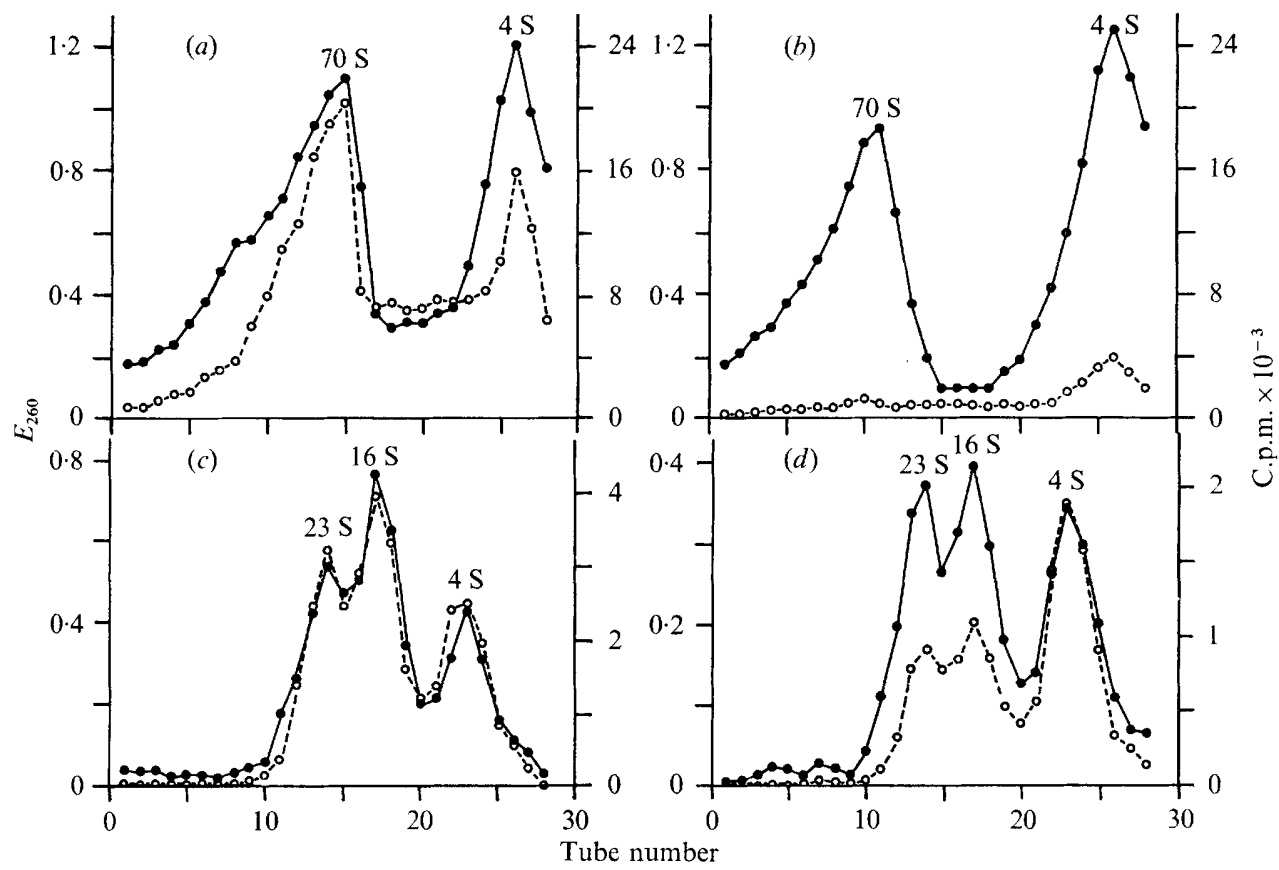

Fig. 7. Sucrose density gradient fractionation of cell-free extracts $(a, b)$ or RNA $(c, d)$ from cells grown in the presence of radioisotopes to label nucleic acids. For ribosomal preparations, $\left[8-{ }^{14} \mathrm{C}\right]-$ guanine added to cultures $15 \mathrm{~min}$. before harvest at identical final turbidities. For RNA preparations, [ $\left.{ }^{32} \mathrm{P}\right]$ phosphate added $15 \mathrm{~min}$. before harvest in another experiment. Cell-free extracts and RNA were prepared as described in Methods, placed on 5 to $20 \%$ sucrose gradients for ultracentrifugation and fractions eluted dropwise by puncture of the bottom of tube and measured: - - - extinction at $260 \mathrm{~nm} ; \mathrm{O}_{----} \mathrm{O}$, radioactivity. $(a)$ and $(c)$, control cells; $(b)$ and $(d)$, cells grown in the presence of $0.4 \mathrm{~mm}$-quinacrine. $70 \mathrm{~s}$ and $4 \mathrm{~S}$ refer to ribosomes and soluble RNA, respectively. $23 \mathrm{~S}$ and $\mathrm{I} 6 \mathrm{~s}$ refer to ribosomal RNA.

Effect of quinacrine on incorporation of nicotinic acid. The uptake of radioactivity from exogenous $\left[{ }^{14} \mathrm{C}\right]$ nicotinic acid which is recovered in the acid-soluble pool fraction of Bacillus cereus (Mandel \& Riis, 1970) was unaffected by the presence of quinacrine (Fig. 9). $\left[{ }^{14} \mathrm{C}\right]$ Nicotinamide incorporation also was unchanged by quinacrine.

Effect of quinacrine on ATP content. The bacterial content of ATP, measured by a luciferas? assay, rose sharply during growth in the presence of quinacrine. Fig. Io reveals that this effect was related to the concentration of the drug in the bacterial medium.

Effect of quinacrine on $\mathrm{K}^{+}$uptake and release. Bacteria grown in the presence of ${ }^{42} \mathrm{~K}^{+}$took up the same amount of this ion whether grown in the presence or absence of quinacrine (Fig. 


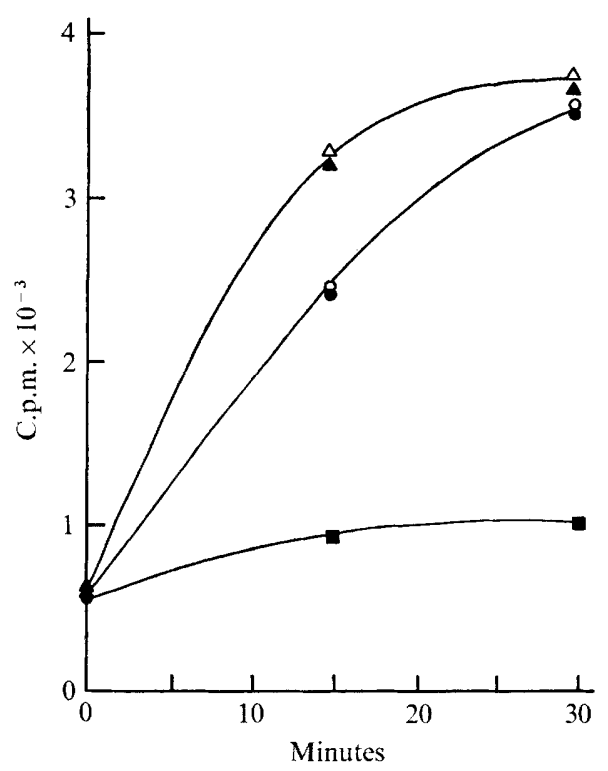

Fig. 8. Incorporation of $\left[{ }^{14} \mathrm{C}\right]$ phenylalanine into polypeptides of Escherichia coli s-30 fractions, stimulated by varying quantities of RNA from Bacillus cereus grown in the presence or absence of 0.4 mM-quinacrine: $\square$, no RNA added; $\Theta, 400 \mu \mathrm{g}$. control RNA; and $\boldsymbol{\Delta}, 600 \mu \mathrm{g}$. control RNA. For RNA from quinacrine-treated cells, $O, 400 \mu \mathrm{g}$; and $\triangle, 600 \mu \mathrm{g}$. With $20 \mu \mathrm{g}$. polyU, got 30,000 c.p.m. after $15 \mathrm{~min}$. incubation.

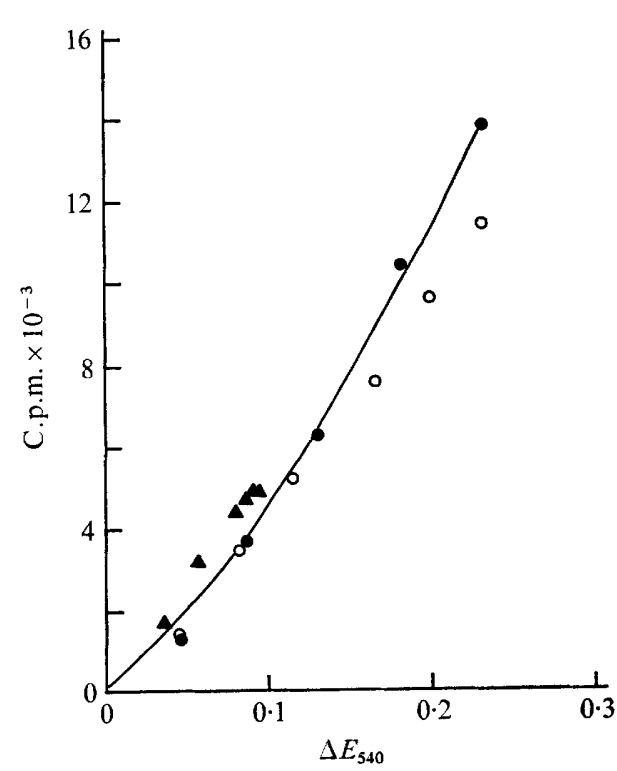

Fig. 9

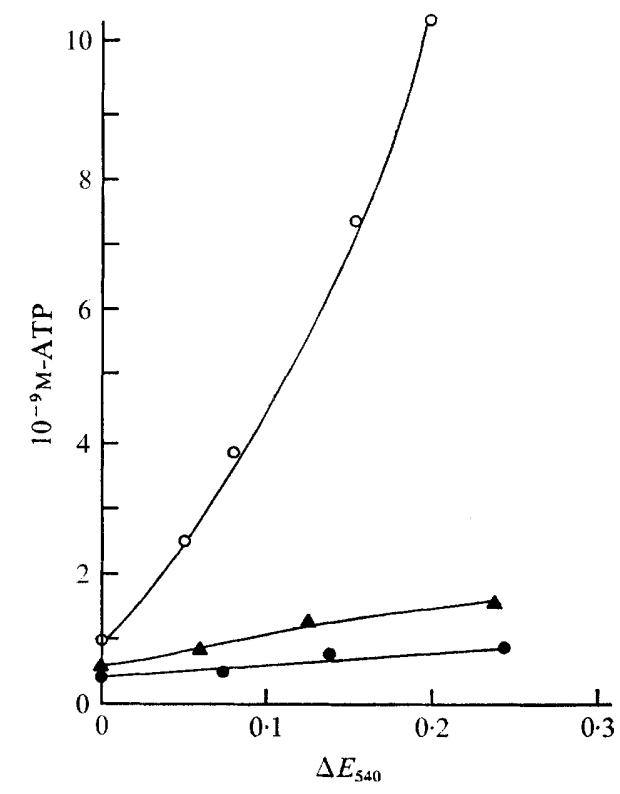

Fig. Io

Fig. 9. Incorporation of radioactivity from $\left[7^{-14} \mathrm{C}\right]$ nicotinic acid into the acid-soluble fraction of cells. Cell samples were rapidly cooled, filtered and washed with I \% sodium chloride. Quinacrine concentrations: 0 , $0 ; \Delta, 0.1 \mathrm{~mm} ; 0,0.4 \mathrm{~mm}$.

Fig. Io. Effect of quinacrine on the ATP content per ml. of bacterial suspension. Almost all of the ATP was present in the bacteria. Presentation as in Fig. 3. Quinacrine concentrations, O, 0 ; $\Delta, 0.1 \mathrm{~mm} ; 0,0.4 \mathrm{~mm}$. 
I 1 a). Bacteria labelled with radio-potassium in the absence (Fig. I $b$ ) or presence (Fig. I $c$ ) of quinacrine and then resuspended in unlabelled medium with or without quinacrine lost ${ }^{42} \mathrm{~K}^{+}$equally in relation to subsequent growth.
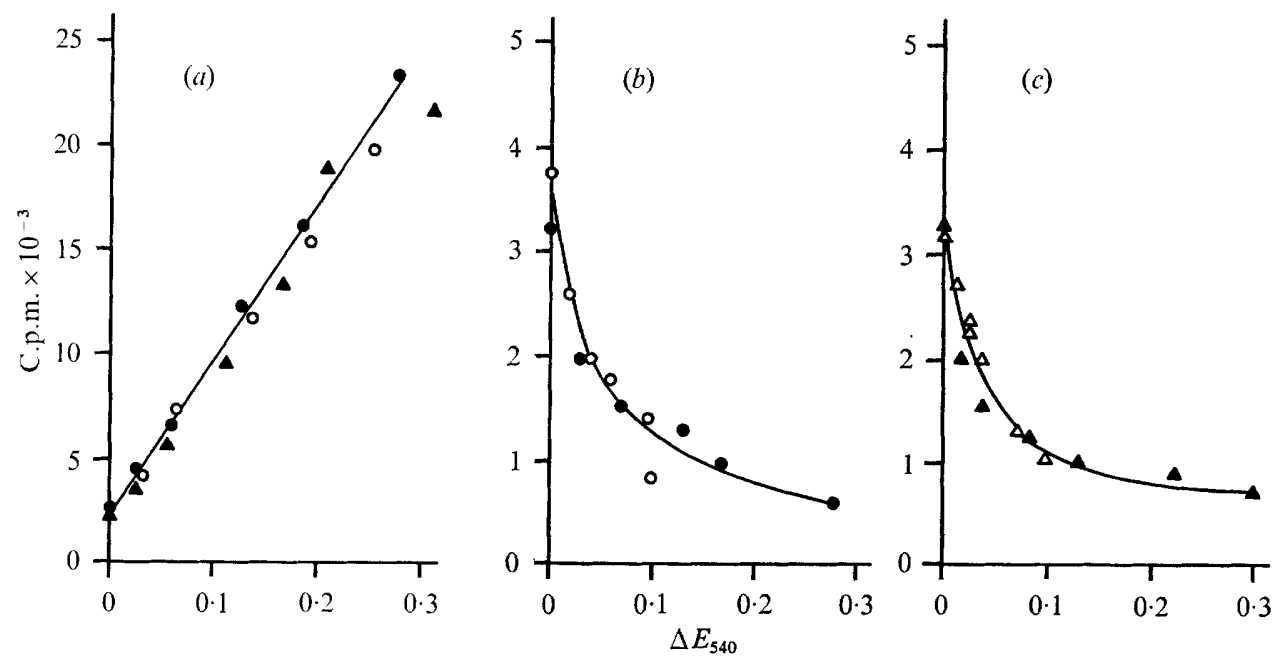

Fig. I I. Lack of effect of quinacrine on the disposition of ${ }^{42} \mathrm{~K}^{+}$. (a) Incorporation of ${ }^{42} \mathrm{~K}^{+}$into growing cells followed by washing with saline, as in Fig. Io. Quinacrine concentrations: $\bigcirc$, o; $\Delta, 0.1 \mathrm{~mm} ; 0,0.4 \mathrm{~mm}$. (b) Release of ${ }^{42} \mathrm{~K}^{+}$from labelled normal cells subsequently grown in the presence $(O)$ or absence (O) of $0.4 \mathrm{~mm}$. quinacrine. (c) Release of ${ }^{42} \mathrm{~K}^{+}$from cells grown in presence of ${ }^{42} \mathrm{~K}^{+}$and $0.1 \mathrm{~mm}$-quinacrine and subsequently recultured in nonradioactive medium in the presence $(\Delta)$ or absence $(\Delta)$ of 0.4 mM-quinacrine.

\section{DISCUSSION}

In this study we examined several of the many reported actions of quinacrine in a single biological system. Special emphasis was given to biosynthetic reactions rather than effects on energy utilization or production, since major dissociations of macromolecular biosynthesis were apparent.

The ability of spermine to antagonize growth inhibition produced by quinacrine in Escherichia coli was recognized a long time ago (Silverman \& Evans, 1944; Miller \& Peters, 1945). Similarly, $\mathrm{Ca}^{2+}, \mathrm{Mg}^{2+}$ and $\mathrm{Mn}^{2+}$ were reported to prevent the drug's bacteriostatic effect on that micro-organism (Silverman, I948). In Bacillus cereus these compounds were able to reverse the actions only of low concentrations of quinacrine, and spermine also partially prevented the depression of adenine incorporation into nucleic acids (Fig. 6). Whether this effect is due to the known stimulation of RNA polymerase by spermine (Krakow, 1963; O'Brien et al. 1966), the amine's ability to displace quinacrine from DNA or the compound's capacity to stabilize ribosomes (Colbourn, Witherspoon \& Herbst, I96I; Hershko, Amoz \& Mager, I96I) is still unclear.

The normal uptake of nicotinic acid and potassium ion, as well as the release of $\mathrm{K}^{+}$, implies that many functions of the bacterial cell continue unchanged in the presence of growthinhibitory concentrations of quinacrine. In several mammalian systems such as cardiac muscle (Armitage, I957) and red blood cells (Kärki, I958) $\mathrm{K}^{+}$uptake has been reported to be diminished by treatment with quinacrine. On the other hand, intracellular ATP levels were increased, probably due to the reported inhibition of ATPase by the drug (Greenawalt, Weibull \& Löw, 1962; Grillo, Rinaudo \& Vergani, 1964). 
The relative insensitivity of DNA synthesis to the action of quinacrine in Bacillus cereus is in distinct contrast to the reported effects of the drug in Escherichia coli. Ciak \& Hahn (1967) have shown that a bacteriostatic concentration of quinacrine in $E$. coli had no effect on the rate of RNA synthesis, reduced the rate of DNA formation to the same extent as that of growth measured turbidimetrically, but produced a somewhat greater depression of protein biosynthesis. A bactericidal concentration prevented DNA synthesis entirely, whereas protein and RNA synthesis continued though at a considerably reduced rate. This selective effect on DNA synthesis of $E$. coli by quinacrine was related to the greater sensitivity of DNA polymerase than RNA polymerase to quinacrine (O'Brien et al. I966). Thus, in $B$. cereus it is unlikely that growth inhibition by quinacrine is due to failure of DNA strand separation and cessation of DNA formation. Instead, RNA biosynthesis was most depressed by the drug.

The difference in the relative magnitude of effects in Escherichia coli and Bacillus cereus may be due to a less stringent control of RNA synthesis in B. cereus, since RNA synthesis was also more susceptible to inhibition by a related growth inhibitor, ethidium, in $B$. cereus than it was in E. coli (Tomchick \& Mandel, 1964). In most other biological systems tested quinacrine affects DNA synthesis preferentially. Thus, DNA formation was almost completely inhibited in tetrahymena, whereas RNA and protein synthesis were depressed by only 70 and $50 \%$, respectively (Chou \& Ramanathan, 1968). In plasmodia, the synthesis of both RNA and DNA was almost completely curtailed by $10^{-4} \mathrm{M}$-quinacrine (Schellenberg \& Coatney, 196I), but van Dyke, Szustkiewicz, Lantz \& Saxe (1969) reported that DNA synthesis was somewhat more sensitive to quinacrine than was RNA synthesis. However, the incorporation of ATP of erythrocyte-free Plasmodium berghei into RNA was claimed to be more inhibited than that into DNA, but the difference was small (van Dyke, Lantz \& Szustkiewicz, I970).

The detailed mechanism of the selective block of RNA formation in Bacillus cereus may be due to inhibition of RNA polymerase by quinacrine, as reported for Escherichia coli (O'Brien et al. 1966). Since the effect was more pronounced on ribosomes or rRNA formation than on sRNA, it is also possible that quinacrine produced a 'shift-down' effect. Other drugs, such as dinitrophenol (Simon, van Praag \& Aronson, I966), levorphanol (Simon \& van Praag, 1964; Greene \& Magasanik, 1967), and azide and cyanide (Nazar \& Wong, 1969) have been observed to produce selective inhibition of RNA synthesis, particularly of rRNA, resembling the action of a more limited nutritive growth medium. Recently it was suggested that salicylate also exhibited such an action in B. cereus (Schwartz \& Mandel, I972).

The normal messenger activity of RNA makes it doubtful that the quinacrine effect was specifically localized at the step of transcription to form mRNA. However, the phenol extraction procedure for RNA from Bacillus cereus probably would have dissociated a complex of quinacrine with mRNA which might have formed in the bacterium. Nevertheless, it was observed that in these organisms protein biosynthesis continued whereas total RNA synthesis was decreased to a much greater extent. Thus, in these micro-organisms, inhibition of the formation of rRNA was most closely linked with growth inhibition.

This work was supported by U.S. Public Health Service research grant AI 04264 from the National Institute of Allergy and Infectious Diseases, N.I.H., Bethesda, Maryland, and grant no. DA-MD-49-193-66-G9I94 from the U.S. Army Medical Research and Development Command, Office of the Surgeon-General, Washington, D.C.

For M.L.S. the research was in partial satisfaction of the requirements for the M.S. degree from The George Washington University Graduate School of Arts and Sciences. 


\section{REFERENCES}

AdDanki, S., Sotos, J. F. \& ReARICK, P. D. (I966). Rapid determination of picomole quantities of ATP with a liquid scintillation counter. Analytical Biochemistry 14, 26I-264.

Armitage, A. K. (1957). The influence of potassium concentration on the actions of quinidine and of some antimalarial substances on cardiac muscle. British Journal of Pharmacology 12, 74-78.

BraY, G. A. (1960). A simple efficient liquid scintillator for counting aqueous solutions in a liquid scintillation counter. Analytical Biochemistry I, 279-285.

Burton, K. (I955). The relation between the synthesis of deoxyribonucleic acid and the synthesis of protein in the multiplication of Bacteriophage T2. Biochemical Journal 6r, 473-483.

Chou, S.-C. \& Ramanathan, S. (1968). Quinacrine. Site of inhibition of synchronized cell division in tetrahymena. Life Sciences 7, 1053-1062.

CIAK, J. \& HAHN, F. E. (I967). Quinacrine (Atebrin): mode of action. Science r56, 655-656.

Colbourn, J. L., Witherspoon, B. H. \& Herbst, E. J. (I961). Effect of intracellular spermine on ribosomes of Escherichia coli. Biochimica et biophysica acta 49, 422-424.

Connamacher, R. H. \& Mandel, H. G. (1965). Binding of tetracycline to the 30 s ribosomes and to polyuridylic acid. Biochemical and Biophysical Research Communications 20, 98-103.

VAN Dyke, K., LANTZ, C. \& SzUSTKIEwiCZ, C. (1970). Quinacrine: mechanism of antimalarial action. Science $\mathrm{r69}, 492-493$.

van Dyke, K., Szustiemicz, C., Lantz, C. H. \& SaXe, L. H. (1969). Studies concerning the mechanism of action of antimalarial drugs. Inhibition of the incorporation of adenosine- $8-{ }^{3} \mathrm{H}$ into nucleic acids of Plasmodium berghei. Biochemical Pharmacology 18, 1417-1425.

Greenawalt, J. W., Weibull, C. \& Löw, H. (1962). The hydrolysis of adenosine triphosphate by cell fractions of Bacillus megaterium. II. Stimulation and inhibition of the enzymic activities. Journal of Biological Chemistry 237, 853-858.

Greene, R. \& MAgasanik, B. (1967). The mode of action of levallorphan as an inhibitor of cell growth. Molecular Pharmacology 3, 453-472.

Grillo, M. A., Rinaudo, M. T. \& Vergani, E. (1964). Participation of flavine derivatives in adenosine triphosphatase reactions of striated muscle. Enzymologia 27, 4I-46.

GrüNBERGER, D. \& MANDEL, H. G. (1965). Enhanced messenger activity of RNA from 8-azaguanine treated Bacillus cereus. Molecular Pharmacology 1, I 57-162.

Hershko, A., AMOz, S. \& MAGER, J. (I96I). Effect of polyamines and divalent metals on in vitro incorporation of amino acids into ribonucleoprotein particles. Biochemical and Biophysical Research Communications $5,46-5 \mathrm{I}$.

IRVIN, J. L. \& IRVIN, E. M. (1954). The interaction of a 9-aminoacridine derivative with nucleic acids and nucleoproteins. Journal of Biological Chemistry 206, 39-49.

KäRKI, N. T. (1958). Effect of quinidine and other antimalarial agents on the uptake of potassium ions by red cells. Archives Internationales de Pharmacodynamie et de Therapie 1r4, 243-249.

KRAKow, J. S. (1963). Ribonucleic acid polymerase of Azotobacter vinelandii. Biochimica et biophysica acta $72,566-57 \mathrm{I}$.

KuRNICK, N. B. \& RADCLIFFE, I. E. (1962). Reaction between DNA and quinacrine and other antimalarials. Laboratory of Clinical Medicine 60, 669-688.

Lerman, L. S. (1963). The structure of the DNA-acridine complex. Proceedings of the National Academy of Sciences of the United States of America 49, 94-102.

MANDEL, H. G. \& RIIS, M. (I970). Interference of barbiturates with pyrimidine incorporation. II. Structural specificity of the inhibition of orotate uptake in Bacillus cereus. Biochemical Pharmacology r9, 1867-1877.

Mandel, H. G. \& Seligman, M. L. (1966). The biochemical effects of quinacrine on growing Bacillus cereus cells. The Pharmacologist 8, $2 \mathrm{I}$.

Mandel, H. G. \& Seligman, M. L. (1967). Disposition and actions of quinacrine in Bacillus cereus. Proceedings of the Fifth International Congress on Chemotherapy, Vienna A I-4/28, 249-252.

Militzer, W. E. (1946). Note on the orcinol reagent. Archives of Biochemistry 9, 85-90.

Miller, A. K. \& Peters, L. (I945). The antagonism by spermine and spermidine of the antibacterial action of quinacrine and other drugs. Archives of Biochemistry 6, 28I -286 .

NAZAR, R. N. \& WoNG, J. T.-F. (1969). Inhibitor-induced shiftdowns in Escherichia coli. Journal of Bacteriology roo, 956-96I.

Nirenberg, M. (1963). Cell-free protein synthesis directed by messenger RNA. In Methods in Enzymology, vol. 6. pp. 17-23. Edited by S. P. Colowick \& N. O. Kaplan. New York: Academic Press. 
O'Brien, R. L., Olenick, J. G. \& HAHn, F. E. (1966). Reactions of quinine, chloroquine and quinacrine with DNA and their effects on the DNA and RNA polymerase reactions. Proceedings of the National Academy of Sciences of the United States of America 55, I5I I-I 5 I 7.

RAlPh, R. K. \& Bellamy, A. R. (1964). Isolation and purification of undegraded ribonucleic acids. Biochimica et biophysica acta 87, 9-16.

Roodyn, D. B. \& MANDEL, H. G. (I960a). A simple membrane fractionation method for determining the distribution of radioactivity in chemical fractions of Bacillus cereus. Biochimica et biophysica acta 4r, 80-88.

Roodyn, D. B. \& MAndel, H. G. (1960 $b$ ). The differential effect of 8-azaguanine on cell wall and protoplasmic protein synthesis in Bacillus cereus. Journal of Biological Chemistry 235, 2036-2044.

Schellenberg, K. A. \& Coatney, G. R. (196I). The influence of antimalarial drugs on nucleic acid synthesis in Plasmodium gallinaceum and Plasmodium berghei. Biochemical Pharmacology 6, 143-152.

Schwartz, C.S. \& MANDEL, H. G. The selective inhibition of microbial RNA synthesis by salicylate. Biochemical Pharmacology (in press).

Silverman, M. (1948). Metal antagonism of the antibacterial action of atabrine and other drugs. Archives of Biochemistry 19, 193-198.

Silverman, M. \& Evans, E. A., Jun. (1944). The effects of spermine, spermidine and other polyamines on the growth inhibition of Escherichia coli by atabrine. Journal of Biological Chemistry 154, 52 I-534.

Simon, E. J. \& VAN PraAG, D. (1964). Selective inhibition of synthesis of ribosomal RNA in Escherichia coli by levorphanol. Proceedings of the National Academy of Sciences of the United States of America $\mathbf{5} \mathbf{I}$, I I 5 I-I I 58.

Simon, E. J., van PraAG, D. \& Aronson, F. L. (1966). The selective inhibition of ribosomal RNA synthesis in Escherichia coli by 2,4-dinitrophenol. Molecular Pharmacology 2, 43-49.

STREHLER, B. L. \& TOTTER, J. R. (1954). Determination of ATP and related compounds; firefly luminescence and other methods. In Methods of Biochemical Analysis, Vol. I, pp. 34I-356. Edited by D. Glick. New York: Interscience.

Tomchick, R. \& MANDEL, H. G. (I964). Biochemical effects of ethidium bromide in micro-organisms. Journal of General Microbiology 36, 225-236. 